\title{
Effect of Extract Black Cumin (Nigella sativa) on the Vaginal Cytology of Ovariectomized White Mouse (Rattus Novergicus Strain Wistar)
}

\author{
Kusuma Andriana $^{1 *}$, Dian Yuliartha Lestari ${ }^{2}$ \\ ${ }^{1}$ Departement of Obstetry and Gynecology, Medical Faculty, University of Muhammadiyah \\ Malang, Indonesia \\ Jalan Bendungan Sutami 188A Kota Malang, Jawa Timur 65145 \\ ${ }^{2}$ Departement of Pathology Anatomy, Medical Faculty, University of Muhammadiyah Malang, \\ Indonesia \\ Jalan Bendungan Sutami 188A Kota Malang, Jawa Timur 65145 \\ *Corresponding author: andrianakusuma@yahoo.com
}

\begin{abstract}
Background: Hypoestrogen in menopausal women causes loss of glycogen, decreased lactic acid production that could rise the vaginal $\mathrm{pH}$ and facilitates the occurrence of infection, irritation and vaginal becomes dry, hot and itchy. The importance of the role of estrogen for women reproduction, encouraging researches to find the source of estrogen from the others. Black cumin is a spice that can be used as a medicinal plant and food preservatives. Objectives: The study aimed to determine the effect of black cumin against changes on vaginal cytology of the ovariectomized white mouse. Methods: This study was true experimental design with the posttest only control group designed with 21 female mouse divided into seven groups: a control negative group, a control positive group, and 5 treatment groups of black cumin extract at a dose of 1.25, $2.5,5,10$ and $20 \mathrm{mg} / \mathrm{kg}$ BW/day. Results: The results result showed the significant differences in intermediate cells changes (p: 0,001), superficial cells ( $p: 0,000)$ and not significant in parabasal cell ( $p: 0120)$. By the Kruskal-Wallis, there was significant difference in vaginal maturation index (p: 0,22). Conclusion: Extract of black cumin had a significant effect on the vaginal cytology of ovariectomized white rats.
\end{abstract}

Keywords: Menopause, Black Cumin Extract, Vaginal Cytology.

\section{INTRODUCTION}

Menopause is defined as the cessation of menstruation after 12 months of amenorrhea due to interruption of ovarian activity. Sign and symptoms vary widely that begins during menopausal transition. The most frequent symptoms are hot flushes, insomnia dan vaginal dryness (Schorge et al, 2008). Changes that occur after menopause in urogenital are decreased vascularisation and elasticity of vaginal wall caused dyspareuni, depletion of epithelium thickness caused post coital beleeding (Bruce, 2009).

Serum FSH measurements are the best laboratory tests for menopausal diagnosis, but the cost of examination is still expensive (Sperof, 2005). Vaginal cytology is an inexpensive way to assess the presence of estrogen. The results of vaginal cytology are obtained (sequentially) parabasal, intermediate, and superficial cells. The more superficial cells get (shift to the right), the higher the estrogen level there is and vice versa (Schorge, 2008). 
The importance of the role of estrogen on female reproductive organs, encourage researchers to experiment to find the source of estrogen from outside the body (exogenous estrogen) as endogenous estrogen replacement that are relatively safe. Hormone replacement therapy (HRT) is being used to relieve postmenopausal symptoms thereby improving the quality of life but prolonged exposure to HRT, however, gives side effects. (Parkizhar, 2011).

Nigella sativa (Black seed) is a spice plant that can be used for traditionally culinary and medicinal purposes (Rhandawa, 2008). Very few studies have reported that N.sativa exhibited antiinfertility, antioxytocic activity, emenagogum, and increase milk production (Malhotra, 2004; Sharma, 2009). N.sativa have been shown to improve lactation in nursing mothers and to regulate menstruation among females in folk medicine but the effect of N.sativa on reproductive organ still uncleared. (Parkizhar, 2011)

\section{METHOD}

The study aimed to determine the effect of black cumin (Nigella sativa) against changes on vaginal cytology of the ovariectomized white mouse (Rattus novergicus wistar strain). This study was true experimental design with the posttest only control group designed with 21 female mouse divided into seven groups : a control negative group, a control positive group, and 5 treatment groups of black cumin extract at a dose of 1.25 , 2.5, 5, 10 and $20 \mathrm{mg} / \mathrm{kg} \mathrm{BW/day} \mathrm{(group} \mathrm{P1,} \mathrm{2,} \mathrm{3,} \mathrm{4,} \mathrm{and} \mathrm{5).}$

Black cumin seeds (N.sativa) were from herbal medicine shop in Malang-East Java Indonesia. Black cumin seeds were extracted by maceration procedure that produced black cumin oil. Previous research has given black cumin extract dose of 2.5 to $5 \mathrm{mg} / \mathrm{kg} /$ day to see the impact of black cumin to repair rat model of rheumatoid artirits, and used as a dose for this study.

Extract of black cumin was done by a sonde into the mouths of mouse, six days a week for eight weeks. At the initial stage before treatment, the mice were adaptation for 1 week then performed ovariectomy. The second adaptation performed at 2 weeks after ovariectomy to get hypoestrogen condition. After eight weeks, mice vaginal specimens are taken by using cytobrush with gentle pressure and rotated clockwise direction $360^{\circ}$. Cytobrush was applied in object glass, allowed to be air-drying and then fixation in $95 \%$ alcohol for 20-30 minutes. The smear then dried, sent to laboratory and stained by the Papanicolau method. Evaluation of cell maturity was interpreted at the light microscope by counting the number of superficial, intermediate and basal/parabasal cells. The number of superficial cells were multiplied by 1 , intermediate cells multiplied by 0,5 and parabasal cells multiplied by 0 . All three cells were summed to get cell maturity value. A maturity value between $0-49$ reflected low estrogen effects, 50-64 reflected intermediate effect and 65-100 reflected high effect (Imelda, 2010).

One way ANOVA was used for statistical analysis which previously conducted normality and homogeneity test as a precondition, if it was not requirement, performed Kruskal-Wallis analysis. The test was significant if $\mathrm{p} \leq 0.05$.

\section{RESULTS AND DISCUSSION}

The highest parabasal cell was in control positive group, intermediate was in P3, and superficial was in P5. Highest maturation index was in P5 and the others were in P4 and control negative group (Tabel 1). The result of one-way ANOVA test were significant for intermediate and superficial cell, and not significant for parabasal cell (Table 2). Kruskal-Wallis test for maturation index was significant with $\mathrm{p}: 0,022$. 
Table 1 The measure of parabasal, intermediate, superficial cell and maturation index.

\begin{tabular}{lllllllll}
\hline \multirow{2}{*}{ Group } & \multicolumn{2}{l}{ Parabasal } & \multicolumn{3}{c}{ Intermediate } & \multicolumn{2}{c}{ Superficial } & \multicolumn{2}{c}{ Maturation Index } \\
\cline { 2 - 8 } & Mean & \pm SD & Mean & \pm SD & Mean & \pm SD & Mean & Interpretation \\
\hline Control (-) & 15,5 & 9,4 & 30,6 & 4,5 & 53,9 & 6,6 & 69,3 & High \\
Control (+) & 31,1 & 3,7 & 47,3 & 9,1 & 21,6 & 5,5 & 45,8 & Low \\
P1 & 23,9 & 17,4 & 35,7 & 6,5 & 40,4 & 11,3 & 58,2 & Intermediate \\
P2 & 23,4 & 8,0 & 45,9 & 8,3 & 30,7 & 16,3 & 53,5 & Intermediate \\
P3 & 22,5 & 7,2 & 47,9 & 2,3 & 29,6 & 5,5 & 53,7 & Intermediate \\
P4 & 12,6 & 3,0 & 29,8 & 1,2 & 57,6 & 3,8 & 72,7 & High \\
P5 & 10,0 & 2,6 & 27,4 & 1,9 & 62,6 & 2,9 & 76,7 & High \\
\hline
\end{tabular}

Table 2 Result of One way ANOVA

\begin{tabular}{lll}
\hline Variable & F value & P value \\
\hline Parabasal cell & 2.090 & 0.120 \\
Intermediate cell & 7.421 & 0.001 \\
Superficial cell & 10.179 & 0.000 \\
\hline
\end{tabular}

Atrophy at the urogenital tract including vaginal mucosa were impact due to estrogen deficiency in menopause. Decreased vascularization and elasticity of the vaginal wall with shortening of the vagina and loss of rugae can lead to dyspareuni. The vaginal epithelium thinning makes it easy for trauma and post coital bleeding. Depletion of the vaginal epithelium also caused loss of glycogen, decreased production of lactic acid so that the vaginal $\mathrm{pH}$ becomes more alkaline (6-8) and facilitates the occurrence of infection. All of these changes cause vaginal irritation, vagina becomes dry, hot and itchy (Malhotra, 2004; Bruce, 2009). Decreased estrogen causes changes in loose connective tissue in the bladder, urethra and pelvic wall. This condition causes dysuria, frequency, nocturia, urgency and recurrent urinary tract infections, as well as pelvic organ prolapse (Finlayson, 2007; Bruce, 2009).

Hormone replacement therapy (HRT) was a therapy by giving estrogen with or without progesterone to reduce the effects of menopause on the body. It could be administered orally, intravaginal or transdermal (Ballagh, 2005). Using estrogen in lower urinary tract dysfunction remains controversial. There are several considerable data to support use of estrogen for urogenital atrophy. The intravaginal route administration correlates with better symptom relief by improving vaginal dryness, cytological findings, dyspareuni, pruritus. (Baber RJ, 2016).

Long HRT administration had side effect to increased risk of incident breast cancer and endometrial cancer. The results of this study were in line with Parkizhar et al (2016), which suggested that N.sativa administration significantly increased blood levels of estrogen, affecting uterotrophic assay and vaginal cornification.

Parhizkar et al. (2011), conducted a study of 40 rats in the OVX and divided into 5 groups (control group given Conjugated Equine Estrogen (CEE), Low dose group of N.sativa (LNS) $300 \mathrm{mg} / \mathrm{kg}$, medium dose of NS (MNS) 600mg / kg and High dose of NS (HNS) $1200 \mathrm{mg} / \mathrm{kg}$. The results showed N.sativa induced cornification and increased levels of estradiol significant at LNS group. Kusuma (2012), obtained significant increase in endometrial thickness compared to the control ovariectomized mouse models. The dose of N.sativa used in this study was 1.25, 2.5,5, 10 and $20 \mathrm{mg} / \mathrm{kg} \mathrm{BW/day.} \mathrm{All} \mathrm{of} \mathrm{these} \mathrm{study}$ showed that $\mathrm{N}$,sativa had an estrogen activity

Parkizhar et al. (2016), "These uterotrophic activities of $N$. sativa could be attributed to the flavonoid content and phenolic compounds of $N$. sativa, which has been proven to possess high estrogenic activity (Liu et al, 2004). As suggested in the previous studies, the effect of $N$. sativa powder on reproductive parameters seem to be dependent on multiple components and the synergistic action of its different constituents including 
nigella mine, soluble fiber, sterols, flavanoids and high content of poly-unsaturated fatty acids (Ibrahim et al, 2014). The mechanisms responsible for the effects of phytoestrogens are not clearly understood but there is suggestive evidence that phytoestrogens could act through two possible mechanisms namely, estrogen receptor-dependent and-independent (Ibrahim et al, 2014). Altaee et al. (2006), was designed to investigate the level hormones in volatile oil of black seed that regulate menstrual cycle. The hormone analysis was done using mini VIDAS software version instrument. The results showed presence of several hormones: estradiol, progesterone, prolactin, testosterone, FSH and LH (table 3)

Table 3 Level of hormones present in N.Sativa (Altaee et al., 2006)

\begin{tabular}{lll}
\hline Hormone & NS* from Mosul Region & NS* from Saudi Arabia \\
\hline FSH $(\mathrm{MUl} / \mathrm{ml})$ & 0.43 & 0.1 \\
LH $($ MUI/ml) & 0.1 & 0.1 \\
Prolactin $(\mathrm{ng} / \mathrm{ml})$ & $<0.5$ & $<0.5$ \\
Progesterone $(\mathrm{ng} / \mathrm{ml})$ & 5.55 & 0.91 \\
Testosterone $(\mathrm{ng} / \mathrm{ml})$ & 1.8 & 0.32 \\
Estradiol $(\mathrm{pg} / \mathrm{ml})$ & 278.56 & 113.48 \\
\hline
\end{tabular}

The finding indicated that N.sativa could probable in the treatment menopausal symptom especially vaginal symptom and possibility using as an alternative nature hormone replacement therapy.

\section{CONCLUSION}

Extract of black cumin (Nigella sativa) had a significant effect on the vaginal cytology of ovariectomized white rats (Rattus norvegicus strain wistar). N.Sative could probably using as an alternative nature hormone replacement therapy.

\section{REFERENCES}

Altaee, A.H., Ewadh, M.J., Zaidan, H.K. (2006). Hormonal contents of two types of black seed (nigella sativa) oil: Comparative Study. Medical Journal of Babylon, 3(1-2), 17-21.

Baber, R.J., Panay, N., Fenton, A, 2016, 2016 IMS Recommendations on women's midlife health and menopause hormone therapy, ISSN: 1369-7137 (Print) 1473-0804 (Online) Journal homepage: http://www.tandfonline.com/loi/icmt20

Ballagh, S.A. (2005). Vaginal hormone therapy for urogenital and menopausal symptoms, Seminars in Reproductive Medicine, 23(2).

Bruce, D., \& Rymer, J. (2009). Symptoms of the menopause. Best Practice \& Research Clinical Obstetrics and Gynaecology, 23, 25-32.

Finlayson, A., Horton-Szar, D., Searle, R. (2007). Menopause in crash course. Endocrine and reproductive systems (p. 133-154). Edinburg: Mosby Elsevier.

Ginsburg, J., \& Prelevic, G.M. (2000). Lack of significant hormonal effects and controlled trials of phytoestrogens. Lancet, 355, 163-164.

Ibrahim, M. R., Hamdan, N.S., Mahmud, R., Imam, M.U., Saini, S.M., Rashid, S.N.A., Ghafar, S.A., Latiff, L.A., \& Ismail, M. (2014). A randomised controlled trial on hypolipidemic effects of Nigella Sativa seeds powder in menopausal women. $J$ Transl Med, 12, 82-89. 
Imelda, A.I., Wantania, J., Suparman, E., \& Lintong, P. (2010). Clinical appearance and vaginal cytology of atrophic vaginitis in postmenopausal women. Indones J Obstet Gynecol, 34(2), 92-96.

Kusuma, A., Fathiyah, S., \& Ervan, D.H. (2012). Effect of extract black cumin (nigella sativa) on the endometrial thickness of ovariectomized white mouse (rattus novergicus strain wistar) (hypoestrogen), Poster Presentation for the Kuala Lumpur 5th FIMA Conference 2012.

Liu, M., Xu, X., Rang, W., Li, Y., \& Song, Y. (2004). Influence of ovariectomy and 17ßestradiol treatment on insulin sensitivity, lipid metabolism and post-ischemic cardiac function. Int J Cardiol, 97, 485-493.

Malhotra, S.K. (2004). Nigella. In Kv Peter (Eds). Handbook of herbs and spices (p. 206214). Crc Press North America.

Parhizkar, S., Abdul, L.L., Sabariah, A.R., Aziz, M.D., \& Parichehr, H. (2011). Assessing estrogenic activity of Nigella sativa in ovariectomized rats using vaginal cornification assay. African Journal of Pharmacy and Pharmacology, 5(2), 137142.

Parhizkar, S., Latifah, AL., \& Parsa, A. (2016). Effect of Nigella sativa on reproductive system in experimental menopause rat model. AJP, 6(1), 95-103.

Randhawa, M.A., 2008 Black seed, Nigella sativa, Deserves More Attention Editorial. $J$ Ayub Med Coll Abbottabab, 20(2).

Schorge, J.O., Schaffer, J.I., Halvorson, L.M., Hoffman, B.L., Bradshaw, K.D. \&, Cunningham, F.G. (2008), Menopause transition Williams gynaecology. New York: The McGraw-Hill Companies.

Sharma, N.K., Ahirwar, D., Jhaded., \& Gupta, S. (2009), Medicinal and phamacological potential of nigella sativa: A review in ethnobotanical review. Bilaspur: School of Pharmacy, Chouksey Engineering College.

Speroff, L., \& Fritz, M.A. (2005). Menopause and the perimenopausal transition. clinical gynecologic endocrine and infertility (5th Ed). Philadelphia: Lipincott Williams \& Wilkin. 